\title{
Occupational accidents with biological material in a school hospital
}

\author{
Acidentes de trabalho com material biológico em um hospital escola \\ Accidentes de trabajo con material biológico en un hospital escuela
}

\section{Katia Maria Rosa Vieira' \\ ORCID: 0000-0003-2988-7437}

Francisco Ubaldo Vieira Jr "

ORCID: 0000-0003-0419-6971

Zélia Zilda Lourenço de Camargo Bittencourt' ORCID: 0000-0002-6796-5515

'Universidade Estadual de Campinas. Campinas, São Paulo, Brasil "Instituto Federal de Educação, Ciência e Tecnologia de São Paulo. Campinas, São Paulo, Brasil

How to cite this article: Vieira KMR, Vieira Jr FU, Bittencourt ZZLC. Occupational accidents with biological material in a school hospital. Rev Bras Enferm [Internet]. 2019;72(3):737-43. doi: http://dx.doi.org/10.1590/0034-7167-2018-0630

Corresponding Author: Katia Maria Rosa Vieira E-mail: katia_rosa@terra.com.br Submission: 08-03-2018 Approval: 03-04-2019

\begin{abstract}
Objective: to analyze occupational accidents with exposure of nursing technicians to biological material in a school hospital. Method: nursing technicians were invited to answer a questionnaire related to occupational accidents with biological material. Results: 275 professionals from 9 hospital units participated. 76\% reported having suffered an accident and the variables "age group" and "employment regime" showed a significant association for accidents $(p<0.05)$. Those hired by the Consolidation of Labor Laws (CLT - Consolidação das Leis do Trabalho) employment regime were 3.5 times more likely to suffer accidents $(p=0.04)$ and institutional capacity building did not show statistical significance $(p>0.05)$. Conclusion: the increase in the number of training did not ensure the reduction of occupational accidents with biological material; and nursing technicians under the age of 30 were more vulnerable. Professionals with a CLT labor contract were more affected than the statutory employees.

Descriptors: Occupational Risks; Accidents, Occupational; Nursing; Public Hospitals; Containment of Biohazards.
\end{abstract}

\section{RESUMO}

Objetivo: analisar a ocorrência de acidentes de trabalho com exposição a material biológico de técnicos de enfermagem em um hospital escola. Método: técnicos de enfermagem foram convidados a responder um questionário relacionado à ocorrência de acidentes de trabalho com material biológico. Resultados: participaram 275 profissionais de 9 unidades do hospital. 76\% declararam ter sofrido acidente e as variáveis "faixa etária" e "regime de trabalho" mostraram associação significativa para ocorrência de acidentes $(p<0,05)$. Os contratados pelo regime de trabalho pela Consolidação das Leis do Trabalho (CLT) apresentaram 3,5 mais chances de sofrerem acidentes $(p=0,04)$ e a capacitação institucional não demonstrou significância estatística $(p>0,05)$. Conclusão: o aumento do número de capacitações não assegurou a diminuição dos acidentes de trabalho com material biológico; e os técnicos de enfermagem com idade inferior a 30 anos foram mais vulneráveis. Os profissionais com vínculo trabalhista celetista acidentaram-se mais que os servidores estatutários.

Descritores: Riscos Ocupacionais; Acidentes de Trabalho; Enfermagem; Hospitais Públicos; Exposição a Agentes Biológicos.

\section{RESUMEN}

Objetivo: analizar la ocurrencia de accidentes de trabajo con la exposición de técnicos de enfermería a material biológico en un hospital escuela. Método: los profesionales fueron invitados a responder un cuestionario relacionado con la ocurrencia de accidentes de trabajo con material biológico. Resultados: participaron 275 profesionales de 9 unidades del hospital El 76\% declaró haber sufrido algún accidente y las variables "grupo de edad" $y$ "formas de trabajo" mostraron una asociación significativa para la ocurrencia de accidentes $(p<0,05)$. Los contratados por la forma de trabajo bajo la Consolidación de las Leyes del Trabajo (CLT) presentaron 3,5 más probabilidades de sufrir accidentes $(p=0,04)$ y la capacitación institucional no demostró significancia estadística $(p>0,05)$. Conclusión: el aumento del número de capacitaciones no ha asegurado la disminución de los accidentes de trabajo con material biológico; y los técnicos de enfermería menores de 30 años fueron más vulnerables. Los profesionales con vínculo laborista en la CLT se accidentaron más que los estatutarios.

Descriptores: Riesgos Ocupacionales; Accidentes de Trabajo; Enfermería; Hospitales Públicos; Exposición a Agentes Biológicos. 


\section{INTRODUCTION}

The International Labor Organization estimates that there are 317 million occupational accidents (OA) worldwide each year, resulting in 321,000 deaths ${ }^{(1)}$.

Health professionals are constantly exposed to the risk of infection of innumerable pathogens after accidental occupational exposure through blood or body fluids, with human immunodeficiency virus, hepatitis B or C being considered the most relevant, given their prevalence among patients ${ }^{(2)}$.

Occupational exposure may occur percutaneously when there is contact with needles or sharps; mucosal, skin-non-integral with dermatitis or open sores ${ }^{(3)}$.

Among the health professionals, the nursing category is considered of great vulnerability, since they are involved in the direct and continuous care for the patients, with several procedures being performed ${ }^{(4-6)}$.

In Brazil, Nursing practice is regulated by the Federal Nursing Board (COFEN - Conselho Federal de Enfermagem) and has $2,032,143$ million professional records. The category of nursing technicians is considered the most numerous, with 1,125,172. In São Paulo State, there are 190,208 records ${ }^{(7)}$.

OA with blood and other potentially contaminated fluids, the professional requires specialized medical attention, blood samples to assess the serological status of the source and injured patient, follow-up and treatment, if necessary ${ }^{(8)}$.

Although there is emotional damage to the worker ${ }^{(9)}$, there is also an economic loss and it is estimated that the mean total (direct and indirect) costs of a single accident is US\$ 861.00, ranging from US\$ 199 to US\$1,691 ${ }^{(10)}$.

For containment of bodily fluids and the possibility of disease transmission, protective measures called Universal Precautions by the Centers for Disease Control and Prevention, adopted internationally, have been formulated and subsequently modified and called Standard Precautions ${ }^{(11,12)}$.

In Brazil, Regulatory Norm 32 (RN 32) defines guidelines for the protection and safety of health service workers, such as provision of personal protective equipment (PPE); in-service training; immunization against hepatitis $B$ and suitable containers for disposing of sharps ${ }^{(13)}$, in addition to defining the Plano de Prevenção de Riscos de Acidentes com Materiais Perfurocortantes (Risk Prevention Plan for Accidents with Sharps), and recommending the use of safety devices ${ }^{(14)}$.

Although occupational exposure is a worrisome factor for professionals, often there is the worker's risk behavior and not compliance with the Standard Precautions, which may interfere in the prevention and predisposition to $O A^{(15-18)}$.

Studies performed in institutions aimed at the care for the OA victims by biological material show that most of the occurrences were with health professionals, with the most affected being nursing technicians ${ }^{(19,20)}$.

Inadequacies of health services and precarious conditions, such as overload, prolonged work, fatigue, permanent education deficiency, unavailability / inadequacies of PPE and insufficient staffing size may be related to OA and culminate in the worker's illness ${ }^{(21-23)}$.

Although there is similarity of the nursing praxis in different institutions, this study is relevant because it was carried out in a large public school hospital, based on the promotion of teaching, research and health care, where nursing technicians perform a high number of invasive procedures in daily life.

Considering the possibility of occupational exposure of nursing professionals, studies and reflections on the possible variables related to OA with biological material.

\section{OBJECTIVE}

This study aims to analyze the occurrence of occupational accidents with exposure of nursing technicians to biological material in a school hospital.

\section{METHODS}

\section{Ethical aspects}

Ethical procedures were followed according to Resolution $466 / 2012$ and the research was approved by the Research Ethics Committee of the University under Opinion 2,242,789 / 2017.

\section{Design, place of study and period}

Cross-sectional study of a quantitative nature carried out in a Public State Public School Hospital, located in São Paulo State countryside, with data collected from September to December 2017.

\section{Sample, inclusion and exclusion criteria}

It was obtained, together with the Human Resources Division of the Institution, the nominal relation of the professionals belonging to the Nursing Department $(\mathrm{N}=1,022)$. The sample size was calculated using a sample proportion of 0.25 , resulting in 275 nursing technicians. Participants were randomly selected, maintaining the proportion (0.25) of the number of technicians in the units: Adult (ACU), Pediatric (Pediatric), ICU Adult (ADUICU) and Pediatric (PED-ICU), Imaging (IMA), Ambulatory Service and Specialized Procedures (SEAMPE), Surgical Center (SC) and Central of Material and Sterilization (CMS).

Nursing technicians who were working at the hospital during data collection period, of both genders, who provided direct or indirect care for patients in the morning, afternoon, evening and administrative work shifts, were included. Professionals who were on leave, medical leave, maternity leave, retired due to health problems or enjoying leisure time were excluded, and those who only performed patient transports.

\section{Study protocol}

The researcher developed a tool for data collection that, after the pre-test with 20 subjects, was adequate in the semantics for a better understanding of the questions.

Participants were invited to answer the questionnaire composed of objective questions that addressed aspects related to socioeconomic characterization, functional status and OA with biological material. 


\section{Analysis of results and statistics}

After data collection, data were inserted into Excel 2016 (Microsoft). Statistical analysis was performed using the BioEstat 5.3 program. The Kruskall-Wallis Test was used to compare means; Chi-Square Test and Fisher's Exact Test were used for analysis of contingency tables; Simple Linear Regression was used to verify the degree of association between two quantitative variables. Comparison between two proportions was performed by Binomial test and the Meta Analysis for comparison between more than two proportions. The Multiple Logistic Regression Analysis was used for combined analysis of multiple variables. For all tests, $\mathrm{p}<0.05$ was considered statistically significant.

The variable "accident/year (OA/year)" was calculated by dividing the number of total accidents of each participant by the respective number of years of work in the institution. The calculation was performed for each participant within the respective age group; and from the individual result the mean was calculated with Standard Deviation.

\section{RESULTS}

275 nursing technicians from 9 hospital units participated in the study in morning, afternoon, evening and administrative work shifts. Table 1 shows data referring to the staff of the institution, as well as of the research participants, distributed in the respective work shifts.

Table 1 - Distribution of total nursing technicians and research participants according to units and work shifts $(n=275)$, São Paulo State, Brazil, December, 2017

\begin{tabular}{|c|c|c|c|c|c|c|c|c|}
\hline \multirow{2}{*}{ Units } & \multicolumn{4}{|c|}{ Staff } & \multicolumn{4}{|c|}{ Research participants } \\
\hline & AD & $\mathbf{M}$ & A & $\mathbf{E}$ & AD & $\mathbf{M}$ & A & E \\
\hline CMS & & 30 & 30 & 25 & & 8 & 8 & 8 \\
\hline IMA & & 16 & 15 & 6 & & 5 & 5 & 2 \\
\hline SC & & 56 & 50 & 23 & & 13 & 14 & 7 \\
\hline SEAMPE & 63 & & & & 17 & & & \\
\hline PED & & 13 & 14 & 26 & & 4 & 4 & 7 \\
\hline REU & & 23 & 23 & 43 & & 6 & 6 & 10 \\
\hline PED-ICU & & 9 & 7 & 16 & & 3 & 3 & 5 \\
\hline ADU-ICU & & 38 & 37 & 76 & & 11 & 10 & 21 \\
\hline$A C U$ & & 109 & 113 & 161 & & 28 & 29 & 41 \\
\hline Subtotal & 63 & 294 & 289 & 376 & 17 & 78 & 79 & 101 \\
\hline Total & & & 1,022 & & & & 275 & \\
\hline
\end{tabular}

Note: Central of Material (CMS), Imaging (IMA), Surgical Center (SC), Ambulatory and Specialized Procedures Service (SEAMPE), Pediatrics (PED), Referral Emergency Unit (REU), Pediatric Intensive Care Unit (PED- ICU) and Adult (ADU-ICU), Adult Care Unit (ACU), Morning (M), Afternoon (A), Evening (E), Administrative Time ( $A D)$.

A sample proportion of $25 \%$ of participants from each unit was considered and the comparison between the proportions of the samples used was statistically the same ( $p>0.98)$.

Participants' ages ranged from 22 to 66 years, with a mean of $41.0 \pm 9.2$ years (Mean \pm Standard Deviation), working time at the institution ranged from one to 34 years, with a mean of $10.4 \pm 7.4$ years. 230 female and 45 male nursing technicians participated in a 30-hour weekly work shift with established shifts.

Data analysis showed that 210 nursing professionals reported having undergone OA with biological material, and 65 reported never having suffered an accident at the institution $(p<0.0001)$.
Table 2 shows the distribution of nursing technicians who reported having or not having undergone $\mathrm{OA}$ in the institution by gender, number of jobs, schooling, employment regime and shift, age group and training.

Table 2 results showed statistical significance among people who reported $\mathrm{OA}$ with biological material and the variables age group and work regime $(\mathrm{p}<0.05)$.

Table 2 - Participants characterization according to whether or not OA with biological material according to investigated variables ( $n=275)$, São Paulo State, Brazil, December, 2017

\begin{tabular}{|c|c|c|c|c|c|c|c|}
\hline \multirow{3}{*}{ Variables } & \multicolumn{6}{|c|}{ OA with biological material } & \multirow{3}{*}{$\mathbf{p}$} \\
\hline & \multicolumn{2}{|c|}{$\begin{array}{c}\text { Yes } \\
(n=210)\end{array}$} & \multicolumn{2}{|c|}{$\begin{array}{c}\text { No } \\
(n=65)\end{array}$} & \multicolumn{2}{|c|}{$\begin{array}{c}\text { Total } \\
(n=275)\end{array}$} & \\
\hline & $\mathbf{n}$ & $\%$ & $\mathbf{n}$ & $\%$ & $\mathbf{n}$ & $\%$ & \\
\hline \multicolumn{8}{|l|}{ Gender } \\
\hline Female & 175 & 76.1 & 55 & 23.9 & 230 & 83.6 & \multirow{2}{*}{$0.85^{*}$} \\
\hline Male & 35 & 77.8 & 10 & 22.2 & 45 & 16.4 & \\
\hline \multicolumn{8}{|l|}{ Number of jobs } \\
\hline 1 & 167 & 77.3 & 49 & 22.7 & 216 & 78.5 & \multirow{2}{*}{$0.49^{*}$} \\
\hline$>1$ & 43 & 72.9 & 16 & 27.1 & 59 & 21.5 & \\
\hline \multicolumn{8}{|l|}{ Employment regime } \\
\hline Statuary & 45 & 60.0 & 30 & 40.0 & 75 & 27.3 & \multirow{2}{*}{$0.0002^{* *}$} \\
\hline CLT & 165 & 83.5 & 35 & 17.5 & 200 & 72.7 & \\
\hline \multicolumn{8}{|l|}{ Schooling } \\
\hline Complete High School & 105 & 71.9 & 41 & 28.1 & 146 & 53.7 & \multirow{3}{*}{$0.06^{*}$} \\
\hline Incomplete Higher Education & 30 & 90.9 & 3 & 9.1 & 33 & 12.1 & \\
\hline Complete Higher Education & 72 & 77.4 & 21 & 22.6 & 93 & 34.2 & \\
\hline \multicolumn{8}{|l|}{ Work shift } \\
\hline Morning & 65 & 83.3 & 13 & 16.7 & 78 & 28.4 & \multirow{4}{*}{$0.39 * *$} \\
\hline Afternoon & 58 & 74.4 & 20 & 25.6 & 78 & 28.4 & \\
\hline Evening & 75 & 73.5 & 27 & 26.5 & 102 & 37.1 & \\
\hline Administrative & 12 & 70.6 & 5 & 29.4 & 17 & 6.2 & \\
\hline \multicolumn{8}{|l|}{ Age group } \\
\hline$<30$ years & 22 & 88.0 & 3 & 12.0 & 25 & 9.1 & \multirow{4}{*}{$0.03^{* *}$} \\
\hline 30 to 39 years & 76 & 69.1 & 34 & 30.9 & 110 & 40.0 & \\
\hline 40 to 49 years & 63 & 75.0 & 21 & 25.0 & 84 & 30.5 & \\
\hline$>50$ years & 49 & 87.5 & 7 & 12.5 & 56 & 20.4 & \\
\hline \multicolumn{8}{|l|}{ Number of Trainings } \\
\hline 0 & 29 & 82.9 & 6 & 17.1 & 35 & 12.7 & \multirow{5}{*}{$0.1^{* *}$} \\
\hline 1 & 76 & 77.6 & 22 & 22.4 & 98 & 35.6 & \\
\hline 2 & 49 & 70.0 & 21 & 30.0 & 70 & 25.5 & \\
\hline 3 & 27 & 67.5 & 13 & 32.5 & 40 & 14.5 & \\
\hline 4 or more & 29 & 90.6 & 3 & 9.4 & 32 & 11.6 & \\
\hline
\end{tabular}

Note: Consolidation of Labor Laws (CLT-Consolidação das Leis do Trabalho), Occupational Accident $(O A),{ }^{* *}$ Chi-Square, ${ }^{*}$ Fischer's Exact Test.

The variables "gender", "number of jobs", "schooling", "work shift" and "number of trainings" did not present statistical significance ( $p>0.05)$.

It was observed that nursing professionals with occupational regime presented greater number of accidents (83.5\%).

The highest proportions of OA occurred in workers aged less than 30 years (88.0\%) and over 50 years (87.5\%), being the same $(<30$ and $>50)$ statistically equal ( $p>0.87$ ).

The mean working time in the institution for professionals aged $>50$ years was $17.9 \pm 7.4$ years (Mean \pm Standard Deviation) and for age $<30$ years was $4.4 \pm 2.1$ years, with statistical differences significant $(p<0.0001)$.

It should be noted that the reported accidents were influenced by the time of institution according to the age group. Older workers tended to have more accidents. Therefore, the result of the Chi-Square's Test for the age group may not represent reality. 
Table 3 shows the mean age, OA number and mean number of accidents per year, by age group.

The mean rate of accidents per year for the age group $<30$ years $(0.748 \pm 1.064)$ was statistically higher than the other age groups $(p<0.03)$ and the Linear Regression Analysis showed no association between age means (within each age group) and the number of accidents per year (OA/year) ( $p>0.12$ ).

Workers aged over 50 years had a mean of $0.243 \pm 0.258 \mathrm{OA} /$ year. The statistical comparison showed equality between them ( $p>0.80)$, although numerically smaller than age groups between $30-39$ years $(0.380 \pm 0.621)$ and $40-49$ years $(0.306 \pm 0.462)$.

Table 3 - Mean age, number of accidents and accident rate per year, by age group, São Paulo State, Brazil, December, 2017. Data as Mean \pm Standard Deviation

\begin{tabular}{lccc}
\hline \multicolumn{1}{c}{ Age group } & Age mean & No of OA & OA/year \\
\hline$<30$ years & $27.0 \pm 1.8$ & 72 & $0.748 \pm 1.064$ \\
30 - 39 years & $34.8 \pm 2.8$ & 224 & $0.380 \pm 0.621$ \\
40 - 49 years & $44.0 \pm 2.9$ & 246 & $0.306 \pm 0.462$ \\
$>50$ years & $54.9 \pm 4.2$ & 205 & $0.243 \pm 0.258$ \\
\hline
\end{tabular}

Table 2 shows the influence of variables on OA in isolation. Table 4 shows the Multiple Logistic Regression and influence of the main factors. For variables selection, $p<0.2$ (Employment regime, schooling and number of trainings) were considered. The variable "age group" was not considered for reasons previously explained.

It can be observed in Table 4 that nursing technicians hired by the CLT employment regime presented 3.5 times more chances of suffering accidents than the statutory ones. The chance of professionals with incomplete higher education suffering OA was 3.6 times higher than those who had a different schooling. There was no influence of the variable "number of trainings" on the chances of suffering accidents ( $p>0.05)$.

The mean trained people was $1.89 \pm 1.5$, and those who did not report accidents were $1.80 \pm 1.11$. The comparison between means did not show significant difference $(p=0.70)$.

Table 4 - The Multiple Logistic Regression of the variables associated with OA with exposure to biological material, São Paulo State, Brazil, December, 2017

\begin{tabular}{lccc}
\hline Variable & P value & OR & CI 95\% \\
\hline CLT employment regime & $<0.0001$ & 3.54 & 1.92 a 6.52 \\
Schooling: Incomplete Higher Education & 0.041 & 3.67 & 1.05 a 12.79 \\
4 or more trainings & 0.14 & -- & -- \\
No training & 0.40 & -- & --
\end{tabular}

Note: Odds Ratio (OR), Confidence Interval of 95\% (CI 95\%), Consolidation of Labor Laws (CLT Consolidação das Leis do Trabalho).

\section{DISCUSSION}

It was found that younger professionals presented higher proportions of OA and higher mean OA/year, suggesting that nursing technicians presented more accidents in the first years of working life, and these results are corroborated by the literature $\mathrm{e}^{(5)}$.

Nursing workers are dedicated to care, and may encounter numerous hospitalized patients in critical condition, with aggressive and agitated behavior, which may hinder their practice and the safe conduct of procedures ${ }^{(24,25)}$.

Several studies indicate that the age of less than 35 years has been significantly associated with sharps injuries and blood or body fluids on the mucosa or skin, which may mean that young, enthusiastic, less skilled workers may incur more of these types of $O A^{(5,26,27)}$. It was observed a high number of people injured in the present study, being indicative of the need for greater follow-up of the young workers for orientation and adequacy in the work activities, with emphasis on the content on biosafety.

Although professionals over 50 years of age were more able to deal with adversity, greater seniority did not ensure a reduction in OA with biological material. These may have underestimated compliance with the Standard Precautions and offered resistance to the use of safety devices because of increased confidence.

The hospital where the investigation was carried out is a state institution that has servers with two contracting regimes: 1) Statutory legal regime, with labor relationship governed by statute composed of norms of public order. 2) Public employees hired by the scheme governed by the $\mathrm{CLT}^{(28,29)}$. Statutory public employees have more assured rights such as prediction of paid absences, premium leave for attendance and labor relations based on job stability, offering greater security for the worker ${ }^{(30-32)}$.

Studies in university hospitals have identified that workers with a higher number of OA, while statutory employees had a high rate of absenteeism in nursing ${ }^{(33,30)}$. CLT workers presented higher proportions of $\mathrm{OA}$, which may be related to lower fruition of slacks, resulting in greater fatigue and stress. These allies with worker dissatisfaction due to differences in treatment due to the existence of different labor regimes may have affected the practice and generated more occupational accidents.

Changes in the labor market demanded the expansion of the education system in Brazil with higher education courses, mostly in private institutions, several of them in the night, allowing the entry of people who work ${ }^{(34)}$. Despite the broadening of access to education, there is the wear and tear of the worker who often performs a double journey to reconcile his professional and academic life. It was observed in the present study that the highest proportion of workers with OA had incomplete higher education.

In nursing, there is a predominance of women who need to reconcile the profession with household chores and child care ${ }^{(35,36)}$. This excess of activities and high mental load of work can cause fatigue and compromise the safe development of activities, resulting in $\mathrm{OA}$ in health professionals ${ }^{(22,37)}$. Therefore, in this context, it is probable that the overload caused by the double journey caused fatigue, lack of attention during procedures and favored increase of accidents.

In order to minimize OA, it is important to emphasize the importance of practices aimed at lifelong education and the proposal of strategies aimed at complying with safety standards that make prevention possible in institutions $s^{(23,38,39,40,41)}$.

Professionals who reported having received zero and 4 or more training had equal proportions of OA with biological material, so the increase in the number of training did not ensure a decrease in accidents, and it is fundamental to review the current model in the institution.

A study carried out in public hospitals identified that training with biosafety content did not reduce the accident rate of 
health professionals and did not provide greater compliance with protection barriers ${ }^{(42)}$.

Institutional investment in training is important as recommended in RN32, but not only to obtain numerical indices. Learning only occurs if there is motivation, valorization and use of scientific knowledge, which are dependent on the preparation and receptivity of the individuals, aspects that need to be rethought during the training planning ${ }^{(38)}$.

PISA Test ${ }^{(43)}$, which evaluates high school students, ranked Brazil in the $50^{\text {th }}$ place compared to other countries and only $17 \%$ of the active population are considered to be literate with a reading ability and understanding of texts ${ }^{(44)}$.

This nonconformity in Brazilian education may have affected the nursing professionals' learning and the current institutional capacity building model may not be effective and fulfilling its role to the satisfaction. Therefore, the introduction of new ways of thinking and acting is a challenge in the teaching-learning process.

University hospitals perform many invasive procedures and require trained nursing staff. Evidence indicates that actions are needed that contemplate proper planning of in-service education and efforts to minimize the influence of possible distortions of learning in practice.

Innovations in practice models can be beneficial, with adaptations that ensure a new paradigm of knowledge empowerment by workers, using active methodologies ${ }^{(45)}$ applied in education activities.

\section{Study limitations}

This study was carried out in a Public School Hospital, at the tertiary level, with specific management characteristics and specific characteristics of nursing care. Although there may be similarity of nursing practice, the comparison of results should be carried out with care, taking into account the specificities of each institution.

\section{Contributions to the fields of Nursing, Health or Public Policy}

The research presents relevant contributions to the fields of Nursing, Health or Public Policy by giving visibility to the OA phenomenon of nursing technicians with biological material. The study provides subsidies for health professionals, especially nurses, to improve the planning of preventive actions aimed at workers' health and to implement in-service education methodology, with a view to integrating professionals into the teaching-learning process. In addition, it enables health professionals to reflect on the environment and working conditions of nursing and develop intervention strategies that allow them to overcome the current challenges.

\section{CONCLUSION}

The increase in the number of training did not ensure the reduction of $\mathrm{OA}$ with biological material, and nursing technicians under the age of 30 were more vulnerable.

CLT professionals suffered more than statutory employees, and those who reported having incomplete higher education had a greater proportion of accidents than those with other degrees of education.

Double journey resulting from the exercise and undergraduate courses in the after/before course hours can lead to overload and fatigue, resulting in a probable increase in the number of accidents, which could compromise the safety and health of the worker.

These results point to the need to review the teaching-learning model and the programmatic content of the training offered to the nursing professionals of the health institution.

\section{REFERENCES}

1. OIT: um trabalhador morre a cada 15 segundos por acidentes ou doenças relacionadas ao trabalho [Internet]. [place unknown]: ONUBR; 2013 [cited 2018 Jul 10]. Available from: http://www.nacoesunidas.org/ oit-um-trabalhador-morre-a-cada-15-segundos-por-acidentes-ou-doencas-relacionadas-ao-trabalho

2. Tarantola A, Abiteboul D, Rachline A. Infection risks following accidental exposure to blood or body fluids in health care workers: a review of pathogens transmitted in published cases. Am J Infect Control [Internet]. 2006 [cited 2019 Mar 25];34(6):367-75. Available from: https://doi. org/10.1016/j.ajic.2004.11.011

3. Ministério da Saúde (BR), Secretaria de Vigilância em Saúde. Prevenção e Controle das Infecções sexualmente transmissíveis do HIV/AIDS e das hepatites virais. Profilaxia Pós-Exposição de Risco (PEP) à Infecção pelo HIV, IST e hepatites. Brasília (DF); 2017.

4. Joyce MP, Kuhar D, Brooks JT. Notes from the field: occupationally acquired HIV infection among health care workers - United States, 19852013. MMWR Morb Mortal Wkly Rep [Internet]. 2015 [cited 2018 May 18];63(53):1245-6. Available from: https://doi.org/10.1111/ajt.13250

5. Zhang X, Gu Y, Cui M, Stallones L, Xiang H. Needlestick and sharps injuries among nurses at a teaching hospital in China. Workplace Health Saf [Internet]. 2015 [cited 2019 Mar 25];63(5):219-25. Available from: https://doi.org/10.1177/2165079915580035

6. Uğurlu Z, Karahan A, Ünlü H, Abbasoğlu A, Özhan Elbaş N, Avcı Işık S, et al. The effects of workload and working conditions on operating room nurses and technicians. Workplace Health Saf [Internet]. 2015 [cited 2019 Mar 25];63(9):399-407. Available from: https://doi. org/10.1177/2165079915592281

7. Cofen: Conselho Federal de Enfermagem. Enfermagem em Números [Internet]. Brasília: Cofen; c2019 [cited 2018 Jul 10]. Available from: http://www.cofen.gov.br/enfermagem-em-numeros

8. Ministério da Saúde (BR), Secretaria de Atenção à Saúde. Exposição a Materiais biológicos [Internet]. Brasília (DF): Ministério da Saúde; 2011 [cited 2018 Jul 10]. Available from: http://bvsms.saude.gov.br/bvs/publicacoes/protocolo_expos_mat_biologicos.pdf 
9. Centers for Disease Control and Prevention (CDC). Workbook for Designing, Implementing and Evaluating a Sharps Injury Prevention Program [Internet]. [place unknow]: CDC; 2008 [cited 2018 May 15]. Available from: http://www.cdc.gov/sharpssafety/pdf/ sharpsworkbook_2008.pdf

10. Mannocci A, De Carli G, Di Bari V, Saulle R, Unim B, Nicolotti N, et al. How much do needlestick injuries cost? A systematic review of the economic evaluations of needlestick and sharps injuries among healthcare personnel. Infect Control Hosp Epidemiol [Internet]. 2016 [cited 2018 May 11];37(6):635-46. Available from: https://doi.org/10.1017/ice.2016.48

11. Centers for Disease Control and Prevention. Perspectives in Disease Prevention and Health Promotion Update: Universal precautions for prevention of transmission of human immunodeficiency virus, hepatitis B virus, and other blood borne pathogens in health-caresettings. Morb Mortal Wkly Rep [Internet]. 1988 [cited 2018 Feb 18];37(24):377-88. Available from: https://www.cdc.gov/ mmwr/preview/ mmwrhtml/00000039.htm

12. Garner JS. Guideline for isolation precautions in hospitals. Infect Control Hosp Epidemiol [Internet]. 1996 [cited 2018 May 14];17(1):54-80. Available from: https://doi.org/10.1017/S0195941700006123

13. Ministério do Trabalho e do Emprego (BR). Portaria $n^{\circ} .485$, de 11 de novembro de 2005. Aprova a Norma Regulamentadora $n^{\circ} 32$ (Segurança e Saúde no Trabalho em Estabelecimentos de Saúde). Diário Oficial da União: República Federativa do Brasil; 2005. Nov 16, Seção 1:p. 54.

14. Ministério do Trabalho e Emprego (BR). Portaria n. 1.748, de 30 de agosto de 2011. Institui o Plano de Prevenção de riscos de Acidentes com Materiais Perfurocortantes e altera a Norma regulamentadora $n^{\circ} 32$ que trata da segurança e saúde no trabalho em estabelecimentos de saúde. Diário Oficial da União: República Federativa do Brasil; 2011. Aug 31, Seção 1: p. 64.

15. Tipple AFV, Souza ACS, Almeida ANG, Sousa SB, Siqueira KM. Acidente com material biológico entre trabalhadores da área de expurgo em centros de material e esterilização. Acta Sci Health Sci [Internet]. 2004 [cited 2018 Apr 25];26(2):271-8. Available from: http://periodicos.uem. br/ojs/index.php/ActaSciHealthSci/article/view/1577/928

16. Ferrer LM, Cianelli R, Norr KF, Cabieses B, Araya A, Irarrázabal L, et al. Observed use of standard precautions in Chilean community clinics. Public Health Nurs [Internet]. 2009 [cited 2018 Mar 05];26(5):440-8. Available from: https://doi.org/10.1111/j.1525-1446.2009.00802.x

17. Özdelikara A, Tan M. Conditions in which nurses are exposed to the hepatitis viruses and precautions taken for prevention. Aust J Adv Nurs [Internet]. 2012 [cited 2018 Feb 10];30(1):33-41. Available from: http://www.ajan.com.au/Vol30/Issue1/Ozdelikara.pdf

18. Mitchell H, Jagger JC, Parker GB. Occupational exposures to blood and body fluid splashes and splatters: a 10-year surveillance collaborative. AOHP Journal [Internet]. 2015 [cited 2018 Feb 10];35(4):24-1. Available from: https://www.aohp.org/aohp/portals/0/ documents/MemberServices/journal/15FallJournal.pdf

19. Almeida MCM, Canini SRMS, Reis RK, Toffano SEM, Pereira FMV, Gir E. Clinical treatment adherence of health care workers and students exposed to potentially infectious biological material. Rev Esc Enferm USP [Internet]. 2015 [cited 2018 Sep 11];49(2):259-64. Available from: https://doi.org/10.1590/S0080-623420150000200011

20. Giancotti GM, Haeffner R, Solheid NLS, Miranda FMA, Sarquis LMM. [Characterization of accidents at work with biological material and their victims treated at a public hospital in Paraná, Brazil, 2012]. Epidemiol Serv Saúde [Internet]. 2014 [cited 2018 Sep 11];23(2):337-46. Available from: doi:10.5123/S1679-49742014000200015 Portuguese.

21. Brevidelli MM, Cianciarullo TI. Psychosocial and organizational factors relating to adherence to standard precautions. Rev Saúde Pública [Internet]. 2009 [cited 2018 May 22];43(6):1-10. Available from: http://dx.doi.org/10.1590/S0034-89102009005000065

22. Nowak NL, Campos GA, Borba EO, Ulbricht L, Neves EB. [Risk factors of accidents with sharp instruments]. Mundo Saúde [Internet]. 2013 [cited 2018 May 10];37(4):419-26. Available from: https://www.saocamilo-sp.br/pdf/mundo_saude/155558/A06.pdf Portuguese.

23. Porto JS, Marziale MHP. Reasons and consequences of low adherence to standard precautions by the nursing team. Rev Gaucha Enferm [Internet]. 2016 [cited 2018 May 09];37(2):e57395. Available from: http://dx.doi.org/10.1590/1983-1447.2016.02.57395

24. Sarquis LMM, Felli VEA. [Accidents with sharp instruments among nursing workers]. Rev Esc Enferm USP [Internet]. 2002 [cited 2018 Jun 02];36(3):222-30. Available from: http://dx.doi.org/10.1590/S0080-62342002000300003 Portuguese.

25. Teles AFS, Ferreira MPS, Coelho TCB, Araújo TM. [Occupational accidents with nursing team: a critical review]. Rev Saúde Col UEFS [Internet]. 2016 [cited 2018 Apr 15];6(1):62-8. Available from: https://doi.org/10.13102/rscdauefs.v6i1.1082 Portuguese.

26. Chalya PL, Seni J, Mushi MF, Mirambo MM, Jaka H, Rambau PF, et al. Needle-stick injuries and splash exposures among health-care workers at a tertiary care hospital in north-western Tanzania. Tanzan J Health Res [Internet]. 2015 [cited 2018 May 10];17(2):1-15. Available from: http://dx.doi.org/10.4314/thrb.v17i2.3

27. Miranda FMD, Cruz EDA, Félix JCV, Lalinke LP, Sarquis LMM. Profile of brazilian workers victims of occupational accidents with biological fluids. Rev Bras Enferm [Internet]. 2017 [cited 2018 Sep 12];70(5):1061-8. Available from: http://dx.doi.org/10.1590/0034-7167-2016-0482

28. Silva IBL. Contratação temporária de servidores públicos: desvirtuamento da exigência constitucional do concurso público. Rev Jur FAMINAS [Internet]. 2011 [cited 2018 Jul 16];7(1):62-97. Available from: http://www.faminas.edu.br/upload/ downloads/20130318134245_862907.pdf

29. Guerra SCS. [Supplementary pension of public servants]. Legis Augustus [Internet]. 2016 [cited 2018 Jul 18];7(1):78-91. Available from: http://apl.unisuam.edu.br/revistas/index.php/legisaugustus/article/view/1031/692 Portuguese.

30. Primo GMG, Pinheiro TMM, Sakurai E. [Sickness absenteeism in employees in a public and university hospital]. Rev Med Minas Gerais 
[Internet]. 2010 [cited 2018 Jun 03];20(2 Supl 2):S57-8. Available from: http://rmmg.org/artigo/detalhes/1034 Portuguese.

31. Tomasi E, Facchini LA, Piccini RX, Thumé E, Silveira DS, Vinholes F, et al. [Epidemiological and socio-demographic profile of primary care workers in the South and Northeast of Brazil]. Cad Saúde Púb [Internet]. 2008 [cited 2018 Feb 22];24(Supl 1):S193-201. Available from: http://dx.doi.org/10.1590/S0102-311X2008001300023 Portuguese.

32. Souza HS, Mendes A. Outsourcing and "dismantling" of steady jobs at hospitals. Rev Esc Enferm USP [Internet]. 2016 [cited 2018 Jun 17];50(2):284-91. Available from: http://dx.doi.org/10.1590/S0080-623420160000200015

33. Miranzi SSC, Gaspar AACS, Iwamoto HH, Miranzi MAS, Dziabas DC. [Work accidents among workers of a public university]. Rev Bras Saude Ocup [Internet]. 2008 [cited 2018 Jun 10];33(118):40-7. Available from: http://dx.doi.org/10.1590/S0303-76572008000200005 Portuguese.

34. Teixeira E, Fernandes JD, Andrade AC, Silva KI, Rocha MEMO, Lima RJO. [Overview of nursing graduation courses in Brazil in the national curriculum guidelines decade]. Rev Bras Enferm [Internet]. 2013 [cited 2018 Jun 14];66(esp):102-10. Available from: http://dx.doi. org/10.1590/S0034-71672013000700014 Portuguese.

35. Galastro EP, Fonseca RMGS. [Masculine and feminine identity from the point of view of health workers at a reproductive health service]. REME Rev Min Enf [Internet]. 2006 [cited 2018 Jun 10];10(1):37-40. Available from: http://www.dx.doi.org/S1415-27622006000100007 Portuguese.

36. Baggio MA, Erdmann AL. The (in)visibility of caring and of the profession of nursing in the relations space. Acta Paul Enferm. [Internet]. 2010 [cited 2018 May 16];23(6):745-50. Available from: http://dx.doi.org/10.1590/S0103-21002010000600005

37. Sarsangi V, Salehiniya H, Hannani M, Marzalehs, MA, Abadi, YS, Honarjoo F, et al. Assessment of workload effect on nursing occupational accidents in hospitals of Kashan, Iran. Biomed Res Ther [Internet]. 2017 [cited 2018 Jul 13];4(8):1527-40. Available from: https://doi. org/10.15419/bmrat.v4i08.226

38. Soares LG. [Multi-causality in nursing work accidents with biological material]. Rev Bras Enferm [Internet]. 2013 [cited 2018 Jun 12];66(6):854-9. Available from: http://dx.doi.org/10.1590/S0034-71672013000600007 Portuguese.

39. Ottobelli C, Vaz MRC, Cargnin MCS, Argenta C, Zanatta RG. [Accidents at work with sharps in the surgical center unit in southern Brazil]. $O$ Mundo da Saúde [Internet]. 2015 [cited 2018 Jul 10];39(1):113-8. Available from: http://bvsms.saude.gov.br/bvs/periodicos/mundo_saude_ artigos/acidentes_trabalho_\%20perfurocortantes.pdf Portuguese.

40. Villarinho MV, Padilha MI, Berardinelli LMM, Borenstein MS, Meirelles BHS, Andrade SR. [Public health policies facing the epidemic of AIDS and the assistance for people with the disease]. Rev Bras Enferm [Internet]. 2013 [cited 2018 Sep 12];66(2):271-7. Available from: http:// dx.doi.org/10.1590/S0034-71672013000200018 Portuguese.

41. Al-Khatib IA, El Ansari W, Aregat TA, Darkhawaja RA, Mansour SH, Tucktuck Ma, et al. Occupational safety precautions among nurses at four hospitals, Nablus District, Palestine. Int J Occup Environ Med [Internet]. 2015 [cited 2018 Sep 13];6(4):243-6. Available from: https://doi. org/10.15171/ijoem.2015.581

42. Caixeta RB, Branco AB. [Work-related accidents in health care workers from public hospitals in Brasilia, Brazil, 2002/2003]. Cad. Saúde Pública [Internet]. 2005 [cited 2018 Jun 12];21(3):737-46. Available from: http://dx.doi.org/10.1590/S0102-311X2005000300007 Portuguese.

43. Organization for Economic Co-operating and Development (OECD). Programme for International Student Assessment (PISA) Results from PISA 2015. [place unknown]: OECD; 2015 [cited 2018 Jul 10]. Available from: https:www.oecd.org/pisa/PISA-2015-Brazil-PRT.pdf

44. IBGE: Instituto Brasileiro de Geografia e Estatística [Internet]. Rio de Janeiro: IBGE; 2010. Censo demográfico 2010: educação e deslocamento [cited 2018 Jul 10]; [about 1 screen] Available from: https://ww2.ibge.gov.br/home/estatistica/populacao/censo2010/educacao_e_ deslocamento/default.shtm

45. Mesquita SKC, Meneses RMV, Ramos DKR. [Active teaching/learning methodologies: difficulties faced by the faculty of a nursing course]. Trab Educ Saúde [Internet]. 2016 [cited 2018 Jul 02];14(2):473-86. Available from: http://dx.doi.org/10.1590/1981-7746-sip00114 Portuguese. 